\title{
Why Novel Sanitary Systems are Hardly Introduced?
}

\author{
Micha Blanken ${ }^{1}$, Cees Verweij ${ }^{2}$, Karel Mulder ${ }^{* 3}$ \\ ${ }^{1}$ Faculty of Technology, Innovation \& Society, The Hague University of Applied Science, \\ Johanna Westerdijkplein 75, 2521 EN Den Haag, The Netherlands \\ e-mail: micha_blanken@live.nl \\ ${ }^{2}$ Faculty of Technology, Innovation \& Society, The Hague University of Applied Science, \\ Johanna Westerdijkplein 75, 2521 EN Den Haag, The Netherlands \\ e-mail: c.verweij@hhs.nl \\ ${ }^{3}$ Faculty of Technology, Policy \& Management, Delft University of Technology, Jaffalaan 5, \\ 2628BX Delft, The Netherlands \\ Faculty of Technology, Innovation \& Society, The Hague University of Applied Science, \\ Johanna Westerdijkplein 75, 2521 EN Den Haag, The Netherlands \\ e-mail: k.f.mulder@tudelft.nl
}

Cite as: Blanken, M., Verweij, C., Mulder, K., Why Novel Sanitary Systems are Hardly Introduced?, J. sustain. dev. energy water environ. syst., 7(1), pp 13-27, 2019, DOI: https://doi.org/10.13044/j.sdewes.d6.0214

\begin{abstract}
Innovations are required in urban infrastructures due to the pressing needs for mitigating climate change and prevent resource depletion. In order to address the slow pace of innovation in urban systems, this paper analyses factors involved in attempts to introduce novel sanitary systems. Today new requirements are important: sanitary systems should have an optimal energy/climate performance, with recovery of resources, and with fewer emissions. Anaerobic digestion has been suggested as an alternative to current aerobic waste water treatment processes. This paper presents an overview of attempts to introduce novel anaerobic sanitation systems for domestic sanitation. The paper identifies main factors that contributed to a premature termination of such attempts. Especially smaller scale anaerobic sanitation systems will probably not be able to compete economically with traditional sewage treatment. However, anaerobic treatment has various advantages for mitigating climate change, removing persistent chemicals, and for the transition to a circular economy. The paper concludes that loss avoidance, both in the sewage system and in the waste water treatment plants, should play a key role in determining experiments that could lead to a transition in sanitation.
\end{abstract}

\section{KEYWORDS}

Sanitary systems, Systems innovation, Transitions, Spatial development, Anaerobic digestion, Lock in, Load factor.

\section{INTRODUCTION}

The world is urbanising rapidly. Urban areas consume more and pollute more per capita than their rural surroundings. Given the pressing need to cut greenhouse gas (and other) emissions and prevent resource depletion, cities should work on more efficient systems [1].

\footnotetext{
${ }^{*}$ Corresponding author
} 
Infrasystems (large systems with a public character [2]) are crucial for a city, they enable high densities of population and economic activities. To reach leaps in the metabolic efficiency of infrasystems, transitions are required. However, the systems are considerably 'locked in'. This paper analyses the laborious journey to innovate urban systems, by analysing case studies on the introduction of novel sanitary systems, in order to analyse main barriers and detect options for transitions in urban infrasystems.

\section{Innovation in urban systems}

Innovation is a process of change that takes place in various different settings at the same time, it is a process that takes place in:

- Systems in which various elements are ordered to carry out a joint task;

- Communities of technical and/or scientific experts;

- Industrial organisations, driven by various discourses regarding profit maximization;

- Markets, in which actors seek to optimise benefits for cost, which, under the right conditions will create an equilibrium between supply and demand [3].

In general, innovation is limited as too rapid and frequent change would be unproductive, innovation is 'creative destruction' in which the value of the existing is lost [4]. Thomas Hughes analysed innovation in large technological systems as the interplay between the system's culture of growth, its inertia, and the unstructured barriers that systems should overcome in their growth [5, 6]. In the 1980's (semi-)evolutionary theories triggered debates regarding the nature of technological system's innovation, is it pre-determined by the nature of a system which creates 'momentum', and by macro scale developments that these systems are confronted with? Or is there scope to steer the course of system's innovation by determined action of individuals and collectives? If the latter is the case, are there specific mechanisms or stages in system's development that might be targeted to enact change? Hughes concept of inertia was reframed by economists as 'lock in' $[7,8]$ although this term tends to underestimate the importance of cultural, educational and organisational features of professional communities that keep systems on their development path.

Two decades ago, scholars developed system's change strategies [9] that were incorporated in the approach of transition management [10-14]. Important in these change strategies was to create, nourish and improve small scale niches in which alternative systems could develop that could possibly overtake incumbent systems $[15,16]$.

However, niche formation in large scale systems, in which huge investments have been accumulated, and that are optimized in a long history is hard. Frantzeskaki and Loorbach discerned distributive, accumulative and communicative infrasystems. Distributive systems create a flow from a central node to users, while accumulative systems create a flow from dispersed users to a central node. Communicative systems create a multidirectional flow between users. The economy of both distributive and accumulative infrasystems is determined by economies of scale and economies of reach, i.e., a larger scale creates benefits in the node, but creates extra cost for transport. As distribution and accumulation tend to become cheaper, while the node part of systems tends to become more expensive (higher quality, higher environmental standards), both infrasystem types tend to become larger. For accumulative systems, like waste and sewage systems, it was suggested that among others, a strategy of introducing pre-treatment nodes might be an effective mechanism to trigger transitions [17]. In fact, one could hope that such a strategy could prevent conflict with the incumbent system as the incumbent system would not be directly jeopardized. However, introducing several pre-treatment nodes in a centralized system generally increases investments, which is only regarded as acceptable if compensated by reducing transport costs. 
Introducing innovative systems in new urban areas could be an alternative strategy for transition, could such small scale novel systems act as learning experiments and seeds of change, i.e., as niches that would fuel change? $[15,16]$.

Urban sanitary systems provide an interesting case for systems innovation as they are more or less present in every city, in a similar basic design. Sanitary systems are criticized for insufficiently cleaning sewage, emitting greenhouse gases, insufficiently contributing to a circular use of minerals, and insufficiently producing renewable energy [18].

In the remainder of this paper, attempts are analysed to set up innovation experiments with novel sanitation systems. Many of these attempts were terminated prematurely. In the final discussion, conclusions will be drawn regarding strategies to reach systems innovations in urban sanitation systems, and in urban infrasystems in general.

\section{METHODS}

In order to analyse the factors involved in the premature termination of innovation in sanitary systems, a large literature study was carried out regarding anaerobic sanitation systems for residential use. The authors participated in 6 national meetings of the Netherlands sewage sector/sewage research. Based on this material, 6 key actors were identified and interviewed. Interview results were checked by triangulation, and storylines were checked and detailed by searching newspaper databases and additional literature.

\section{RESULTS}

In this section, the case studies regarding the introduction of novel anaerobic sanitation are presented. First, the history of current sanitation systems is briefly sketched, afterwards, the anaerobic process, and anaerobic sanitation systems are introduced, and finally the case studies are presented.

\section{The emergence of sanitary systems}

In Europe, sanitary systems mainly emerged in the second half of the $19^{\text {th }}$ century to improve public health in residential areas. In fact, these systems merely removed the excrements, often in combination with the removal of excess precipitation, to rivers downstream of cities. In the early $20^{\text {th }}$ century, Waste Water Treatment Plants (WWTP) were added to these systems to cut back environmental pollution and maintain the quality of ecosystems [19]. The processes used microbes that consumed the organic materials and that replicated under aerobic conditions (with much oxygen). To accelerate the process, part of the replicated microbes of the outflow were fed into the inflow of the treatment process. The microbes and remaining substances in the wastewater were removed as sewage sludge. This sludge could be used as agricultural fertilizer. The result of the overall process was that the organics of the wastewater were mainly transformed into Carbon dioxide $\left(\mathrm{CO}_{2}\right)$, first by the microbes in the process, and afterwards by organic decomposition of (microbes and remaining organics in the) sludge. This history was a major determinant of the layout of current sewage systems.

The $21^{\text {st }}$ century brought new challenges for sanitary systems:

- Climate change mitigation required cutting back on greenhouse gas emissions and becoming more energy efficient, even energy producing;

- Adaptation to the impacts of climate change required rethinking the hydrological properties of sanitary systems;

- Depletion of resources on a world scale, and the negative consequences of the remaining pollution by sanitary systems required recovery of materials and energy; 
- Due to increasing levels of contaminants in sewage, and by the risk of biohazards, sewage sludge was increasingly incinerated instead of being used as agricultural fertilizer. This implied a breach of the mineral circle agriculture-food-sewage-agriculture [20].

\section{Anaerobic sewage treatment}

Given these new demands, sanitary systems have been improved [20]. However, also new routes have been explored. Organic materials can also be decomposed by microbes under anaerobic (oxygen-free) conditions. Under oxygen-free conditions, the aerobic microbes are unable to replicate, and the anaerobic microbes dominate. These anaerobic microbes decompose organics into methane. This process can sometimes be observed in deep (especially tropical) lakes that contain high levels of organic materials [21]. Methane should be used as an energy source, and not be released, as methane is a very potent greenhouse gas.

Ever since the $19^{\text {th }}$ century, sewage and sewage sludge was sometimes treated anaerobically, after aerobic treatment in a WWTP, the resulting sewage sludge was treated anaerobically to destroy pathogens. As a by-product of this anaerobic digestion methane was formed, that could be used as a fuel.

Direct anaerobic treatment of sewage was generally impossible. The anaerobic process was slow and as the sewage was much diluted, the anaerobic process required very large basins. A breakthrough occurred by developing a process that kept the microbes in the reactor. In this way, no new microbes had to grow before any treatment could occur, and processing time was greatly reduced. Gatse Lettinga from Wageningen University achieved this by fixing the microbes to sand particles. A filter permitted water to flow through the reactor but trapped the microbe-sand particles. This led to the relatively small Up flow Anaerobic Sludge Blanket (UASB) reactor. The reactive sludge is kept in solution by the equilibrium of gravity and the upward flow. The biogas, a mixture of methane and $\mathrm{CO}_{2}$ that is formed in the process is caught by a 'hood' and can be used as fuel (see Figure 1) [22, 23].

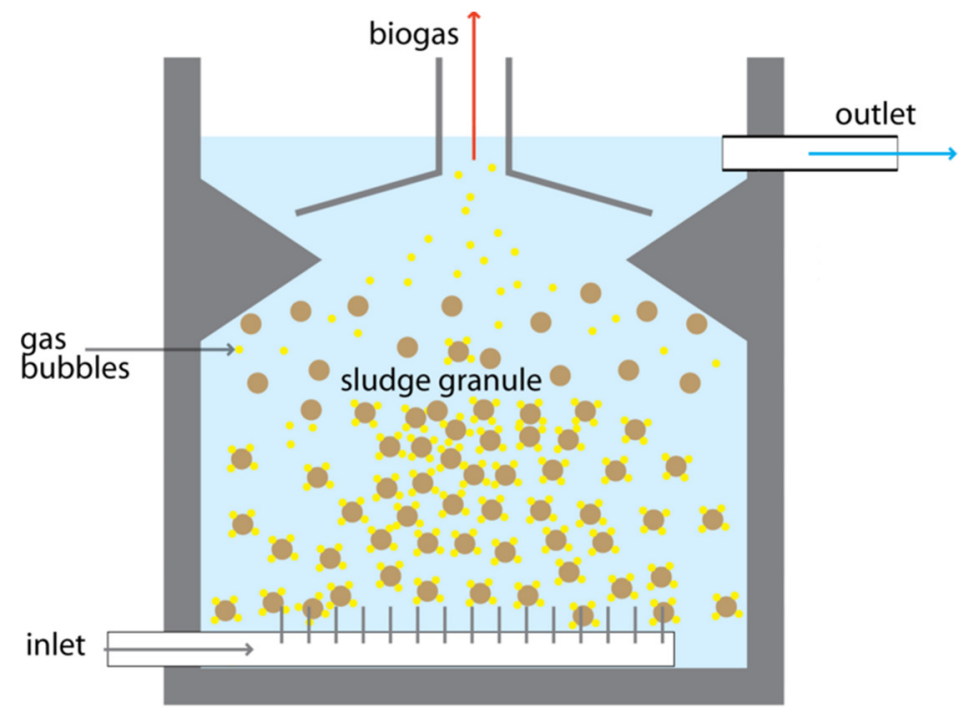

Figure 1. Scheme of UASB reactor (the sewage enters from below, and leaves at the top, the sludge is kept in solution by the equilibrium between flow and gravity, the biogas is collected by a hood)

The UASB reactor was rather successfully introduced for the treatment of (agro-) industrial waste water. It's main advantages were a higher efficiency in biogas production, less heat consumption, and better digestion of organic contaminants 
(e.g. pharmaceuticals). The production of sludge is low, and so sludge removal costs are low. The biogas can be used for energy (after cleaning). The main disadvantages of anaerobic treatment are the long start up times of the reactor, and the problem to deal with diluted and variable waste water [24]. For less concentrated and smaller flows, UASB was less successful. Manure treatment was economically less successful and sewage was often too much diluted to be of interest for anaerobic digestion.

For anaerobic sewage treatment, the organics should not be diluted. Hence, a different sewage system was required, by which 'black water' (excrement and food scrap) was separated from grey water (from laundry, shower). To produce concentrated black water, vacuum toilets were to replace water closets [25].

\section{Case studies: Novel sanitation}

This paper will first briefly describe the performance of novel anaerobic systems in terms of energy, materials recovery, emissions, costs and consumer convenience. It will then describe a number of cases in which attempts were made to introduce these systems, and finally, the paper will reflect on the factors described above, to explain the success/failure of introducing anaerobic waste water treatment.

The anaerobic process has been successfully applied in industrial waste water treatment. However, the anaerobic process requires a far higher concentration of organic materials than the aerobic process. For treating household sewage by an anaerobic process, all water with low concentrations of organic materials has to be kept from the system. The organic concentration should be maximised by:

- Not allowing any precipitation to enter the system;

- Not allowing organic-poor water flows, like shower water, etc., to enter the system;

- Using no-flush toilets (aircraft toilets).

To increase the organic content of sewage, organic kitchen waste might be added [by using a kitchen waste disposer that grinds organic waste (see Figure 2)].

The overall advantages of such an anaerobic wastewater system are an overall increase in biogas production, reduced pollutant levels in the effluent, a reduction in water consumption, and a reduction in kitchen waste to be collected and processed.

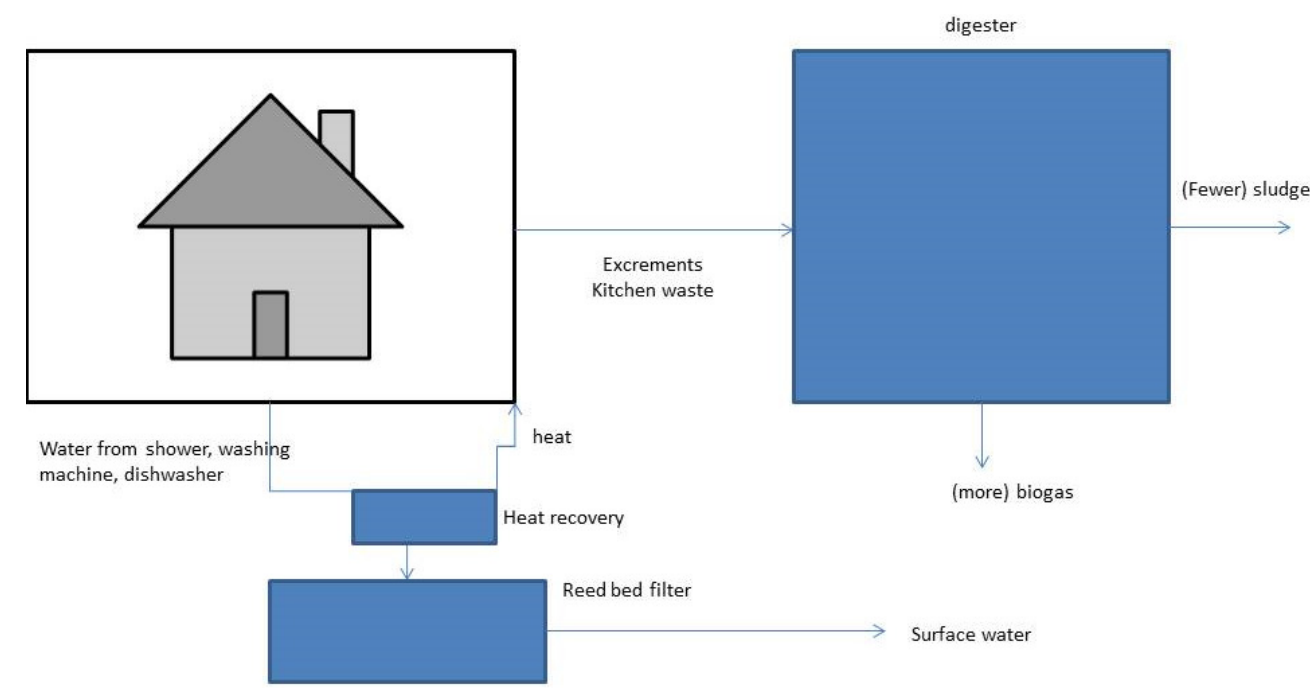

Figure 2. Scheme for 'Novel sanitation'

\section{The first experimental projects}

In several European countries, experiments have been carried out aiming at introducing anaerobic sanitation. Generally, these experiments aimed at anaerobic 
digestion of black water (excrements and food scrap) like in Sweden [26, 27] and Lubeck, Germany [28]. Some attempts to set up anaerobic sewage treatment systems were interrupted or discontinued, e.g. in Freiburg, an anaerobic sewage system was planned and partially constructed, but the digesters were never placed as the German Federal $\mathrm{R} \& \mathrm{D}$ subsidies for studying the performance of anaerobic systems went to a similar project in Flintenbreite, Lubeck. Only one model-house in Freiburg installed an anaerobic digestion system [29].

To analyse factors influencing the successful introduction of anaerobic sanitation systems, only case studies from the Netherlands are analysed. By this choice, the cases are more compatible, as they all are situated in a similar cultural/organisational and political context. A specific feature of sanitation systems in the Netherlands is that responsibilities are divided between municipalities and water boards. Municipalities are responsible for collecting sewage and precipitation and transporting it to a WWTP. The WWTP, however, is under control of a regional water board. Water boards are independent public bodies that are responsible for qualitative and quantitative water management within their territory. To cover the cost of their activities, water boards tax the inhabitants and landowners of their territory. First attempts to introduce anaerobic sanitation systems in the Netherlands started in 2001. A government funded research programme (EET-DESAR), was set up by Wageningen University researchers. DESAR aimed at field trial experiments with anaerobic digestion of sewage. The programme, lasting 5 years, aimed at setting up experiments in 4 different municipalities.

\section{Wageningen}

A first test site for anaerobic sanitation was planned in Wageningen, the same city where the researchers worked. The researchers were supported by the mayor and aldermen of the municipality. The project aimed at installing an anaerobic sewage treatment system for 20 newly built apartments. The project developer aimed at selling high priced apartments. The 'green image' was a pro, but the developer feared noise and stench problems, buyers of such high priced apartments should be offered the choice of not having a vacuum toilet. Of course if any buyer would install a normal toilet, the whole anaerobic system would become dysfunctional because of too much water in the digester.

"The municipal public works department's civil engineers did not share the commitment of their city alderman. They preferred a traditional sanitation system. Finally, the municipality withdrew their support based on the argument that the proper maintenance and operation of the system could not be guaranteed after the EET-DESAR project would be terminated [27]".

\section{Emmen}

A second project was planned for the expansion of a village within the municipality of Emmen. Various scenarios were made for a local anaerobic sanitation system. However, the steering committee of this village expansion project objected to all local sewage treatment plans. The regional water board, the public works department of the municipality and two engineering consultant companies were the main opponents to the project. Uncertainty about funding and know how that was required for future control and maintenance of the proposed system were the main issues of consideration. A further argument was that users should not know about the innovation, and should not notice $\mathrm{it}^{\dagger}$.

\footnotetext{
$\dagger$ It is remarkable that this argument can also be found in the Hammarby Sjöstad project in Stockholm, and that it signified a strategy that probably has been negative for the environmental success of that project - Pandis Iveroth, S., et al., Implications of Systems integration at the Urban Level: The Case of Hammarby Sjöstad, Stockholm, Journal of Cleaner Production, Vol. 48, pp 220-231, 2013
} 
The future inhabitants could not be entrusted to use the new toilets in the appropriate way [27].

\section{Sneek 1}

A third project took place in Sneek, a town in the North of the Netherlands. The project team consisted of Wageningen researchers, the local municipality, two local housing corporations, the regional water board and two local companies specialized in wastewater technology and in vacuum systems. By involving local 'innovative' water actors, a stronger social network was created that supported the project. Moreover, one of the priorities of this network was to make arrangements for the management and control of systems, after the EET-DESAR project would be finished. For the municipality, a main consideration was promoting itself as an innovative, green, water city. Water innovation was the spearhead of the region, and Sneek opted for regional visibility. Within the Netherlands, the city of Sneek is well known for its large lake, and the annual regattas that take place on it.

The anaerobic system with vacuum toilets was realized in 32 new dwellings in Sneek. The anaerobic digester was placed in the garage of the project leader Brendo Meulman (Desah company), who lived in the area. The tenants of the dwellings did not explicitly opt for this type of sanitation. They were informed during a meeting. They received special toilet cleaning detergents that would not devastate the anaerobic treatment process.

An objection against the new system turned out to be the noisiness of flushing: waking up the whole family prevented people from flushing at night. This problem could be countered by technical measures. It turned out that users did not have strong views regarding the system: some definitely liked it while others would have preferred a conventional toilet. The project team had emphasized water saving as a main advantage for the users. However, for the users other arguments prevailed, like the high tech image of the toilet, easy cleaning, noise and the environmental contribution of the system [27].

\section{Attempts to create larger scale novel sanitation}

After the success of Sneek 1, larger scale experiments were crucial for the further development of novel sanitation.

\section{Noorderhoek Sneek}

In 2008, designs were made for a larger scale anaerobic sanitation project to be built in Sneek. Initiators were the municipality, two public housing companies, the regional water board, with Wageningen University and the joint research station of the water boards (STOWA) as important lobbyist at the background. In the Noorderhoek area of Sneek, 282 worn out dwellings would be replaced by 232 new ones. The positive evaluation of the previous small scale project, the commitment of the municipality, the policy of the provincial authorities aiming to make the province of Friesland 'the centre of water innovation', the involvement of two local companies were all important factors that supported the novel sanitation project, that was named 'Waterschoon' (water clean). The regional water board did not oppose the project although it had sufficient capacity in its nearby WWTP.

The existing 32 dwellings with anaerobic sanitation generated a lot of media attention. Media and foreign delegations visited the area. State secretary Huizinga was impressed when Sneek alderman Bargboer showed her the area in February 2009. She invited him to apply for a newly created environmental innovation subsidy [30].

By the end of 2009, the Noorderhoek urban development project was in problems as the economic recession started hitting the building sector. The project had to be delayed, as market demand for housing collapsed. The municipality had to cut budgets in order to 
pay the interests of unused building lots [31], but additional subsidies were acquired for the novel sanitation system. The Netherlands government subsidised the project by the 'unique opportunities program', and further subsidies were acquired from the European Fund for Regional Development. In total, the costs for the novel sanitation system in the area were 1,96 million EUR: 1,27 million for the local anaerobic digester and the remainder for the vacuum sewers and the toilets and grinders in the dwellings. The system was designed for 550 inhabitants, but the digesters could accommodate at maximum 1,200 inhabitants [25].

November $30^{\text {th }} 2009$, construction activities finally started in the Noorderhoek area, almost two years after the first dwellings in the area had been demolished, construction started with a care centre and the sanitation building [32]. Almost two years later, November $18^{\text {th }} 2011$, crown prince Willem Alexander opened the system [33]. The area consisted at that time of 62 dwellings (mainly in the care centre), with 79 inhabitants. This was only a fraction of the intended 550 inhabitants. The evaluation of the results of Waterschoon in 2014 was by large carried out by extrapolating these small numbers. Based on 79 inhabitants, the system would cost each inhabitant about 1,900 EUR per year. However, extrapolations aiming at $90 \%$ use of the digesters (1,080 inhabitants) resulted in costs of 73 EUR per inhabitant per year compared to 65 EUR for a conventional reference system [25]. As the recession gradually faded away, the financial results of the exploitation of the Waterschoon system improved. The costs mainly consisted of a part time operator as a large part of the investments was covered by subsidies. The municipality was quite satisfied as Sneek was put 'on the map' as an innovative water town. However, to continue the project from 2015 to 2017 an additional 645,000 EUR was needed that was jointly covered by project partners. It was estimated that Waterschoon would be in the black by the end of 2017 [34].

\section{Westland}

In 2005, the Innovation Network (IN) of the government Department of Agriculture presented a plan for developing new mixed residential/horticulture areas. The core idea was that substantial symbiosis could be achieved if horticulture was combined with a residential area [35].

Horticulture had a very high energy consumption caused by heating the greenhouses during winter. However, during summer, greenhouse crops had to be protected from the sunlight. In the late 1990's, an extreme efficient air to air heat exchanger was invented (FIWIHEX) [36], that enabled a new heating system for greenhouses. If (large parts of) the roofs of greenhouses were used for solar heat generation in summer, this low quality heat could be stored underground, and be used for heating the greenhouses in winter. The same system could even be used for cooling in summer. Soon it appeared that under normal Netherlands conditions, such a system would actually produce excess heat. 'An energy producing greenhouse' was an appealing idea although it also raised some resistance as being a too technologically focussed approach for sustainabilising agriculture [37].

The idea emerged to combine a residential area with horticulture in order to achieve a balance in heating demand and supply. But such a combination opened additional options: excrements, food scrap and organic waste from horticulture could jointly be digested to produce biogas. Biogas incineration produced $\mathrm{CO}_{2}$ that could be injected in the greenhouses to stimulate plant growth. Grey water (water from showers and laundry) and the digester effluent could be used as 'enriched' water for watering greenhouse plants (such water has higher levels of minerals). This pack of ideas to develop a symbiotic residential/horticulture area was branded 'De Zonneterp' (the solar mound).

The 'Zonneterp' was promoted in one of the two main horticulture regions of the Netherlands, the Westland. In 2007, two local energy/horticulture companies, Priva and 
Aquaterra carried out a first 'exploration of opportunities regarding the options for a specific site to be developed, the Poelzone'. This area had various scattered (horticulture) activities and some dwellings. By restructuring it, horticultural companies could operate more efficiently, new nature could be developed and 1,200 new dwellings could be built. Priva and Aquaterra preferred a conventional flushing sewage system for the area. Concentration of organics should in their view be done before treatment, i.e., before anaerobic digestion of organics.

The municipality created a platform for these plans with the regional water board, the province, the real estate developer ONW (50\% owned by water board, province and municipality, and 50\% owned by the national bank for municipalities), and the local horticulture associations. Besides these actors, there was a consultant that analysed the business case, national government that covered part of the costs, IN that was promoting horticulture innovation and the Wageningen researchers and their anaerobic digestion partners that aimed at introducing anaerobic sanitation. In 2010, a report was published by the Wageningen researchers, a water board, STOWA, IN, the Sneek Company that implemented anaerobic sanitation there (Desah) and an engineering consultancy. In the report various scenarios for anaerobic sanitation were presented, and the conclusion was that two of the scenarios should be further elaborated [38].

Gradually the supporting network for the Zonneterp idea deteriorated. The complexities of the technological arrangements, the large number of relations that had to be negotiated and the potential conflicts of interests took long time to analyse and arrange. ONW started requesting a deadline to be able to commence developing the area. The national government decided to close down the IN (the initiator of the idea) and make horticulture innovation a responsibility of the horticulture sector itself. As a result, the social network that carried developments was crumbling: the water board had a somewhat half-hearted position, as it supported environmental innovation, but also realised that the Zonneterp would imply that part of the capacity of it's new and efficient WWTP would be idle if the Zonneterp would become in use. Finally, the project was abandoned after ONW's deadline could not be met.

After the decision was taken to quit, it turned out that the deadline had been pointless. For several years, nothing happened as there was no demand for new housing due to the recession.

\section{Bio Rio}

The busiest railway line of the Netherlands, the Rotterdam-The Hague connection, has been cutting the city of Delft in two parts for more than a century. The city has been suffering from this divide. In the early 2000's, the decision was made to double the number of tracks to 4, and, in Delft, build a tunnel for these tracks. Delft had to contribute financially to the project. Part of this money would be generated by developing the area on top of the tunnel: the new urban area 'Spoorzone Delft'.

The municipality of Delft created a joint venture with Prorail (owner of railway infrastructure in the Netherlands) to develop the area. The other main stakeholders in the project were the regional water board and Ballast Nedam, the company that did the construction works. The works would be rather complicated as the new railway tracks should be constructed more or less underneath the existing ones, while the existing ones should remain operational. Moreover, a canal cut the area.

In 2011, two consulting companies created an environmental measures long list for the municipality. These measures should lead to a 'Breeam excellent' status for the new 'Spoorzone Delft' area. Novel anaerobic sanitation was one of the proposed measures. Engineering consultancy Tauw assessed technical-economic options for anaerobic sanitation. By the end of 2013 it concluded that anaerobic sanitation would be technologically feasible but economically a doubtful activity. Additional money was 
required, especially as the local anaerobic digester would be extra costs, the regional WWTP was nearby, and had sufficient capacity for treating the sewage of the area.

The municipality estimated that the extra money could perhaps be generated if the novel sanitation system would be an experimental facility. The organisation Clean Tech Delta (association of environmental industry and environmental research organisations in the Rotterdam area) was approached to attract new partners for developing the system as a large scale experiment. This attempt was unsuccessful [39].

There was only one option left to create novel sanitation for the Spoorzone: to charge the new home-owners and tenants. However, the whole project was initiated when economic prospects were bright. The recession had not stopped the project, but real estate prices were falling. In 2014, the Spoorzone project had drained the capital of the municipality, the municipal budget turned red, even after severe cuts in the municipal expenditure [40]. Moreover, the building densities that had been planned for 'Spoorzone' were rather high, which also created a financial pressure on the project. Hence, it was regarded as unrealistic to increase costs for the future inhabitants, i.e., prices/rents for buyers/tenants. These developments combined made the conclusion inevitable: to refrain from anaerobic sanitation [39].

\section{Apeldoorn}

In Apeldoorn, a 150,000 inhabitant city in the central-East part of the Netherlands, plans were made for a hybrid novel sanitation system, the sewage system was a separated grey water/black water system. The black water system was a vacuum system. However, the black water would not be fed into a local anaerobic digester, but into the anaerobic digester that the local WWTP used to treat the sewage sludge that was produced by its aerobic treatment. In this way, one attempted to combine the advantages of the novel anaerobic sanitation method with a conventional waste water treatment system in order to keep investments as limited as possible. To keep investment minimal, transport of raw sewage occurred in part by tanker-lorry [41]. Evaluations of this project are not available yet.

Most recently, the city of Amsterdam decided to implement novel anaerobic sanitation in a new urban area of 550 dwellings. Construction will start in 2018. Studies are made to apply novel anaerobic sanitation for a new island area of 8,000 inhabitants to be constructed after 2020 [42]. This is especially attractive as the area is far removed from an existing WWTP.

\section{DISCUSSION: WHY IS IT SO HARD TO APPLY NOVEL SANITATION IN NEW URBAN AREAS?}

Premature termination of anaerobic sanitation projects was in general not determined by a single issue. It was often a combination of various factors that undermined not only the business case but especially the spirit of the stakeholders. After one actor quits, other actors start renegotiating relations, which deteriorates the whole actor network. This is a well-known phenomenon in innovation theory: most innovations meet with problems and resistance creating frustration among stakeholders. For this reason, a 'champion' of the innovation [43] or an effective 'translator spokesman' [44] is important to prevent recurring issues and keep all stakeholders aligned. In the remainder of this section, the factors involved in the termination/continuation of the case studies will be discussed.

\section{Economy}

All of the Netherlands territory is divided into water board areas that offer sanitation to about $99.5 \%$ of the inhabitants. In fact, every novel sanitation experiment competes with the WWTP of the regional water board. The WWTP's of the water boards are 
generally large scale and have been optimized in a long history. It would be a miracle if small scale anaerobic sanitation could beat the existing WWTP economically.

In that respect, it seems quite exceptional that this competition has not caused the water board in Sneek to resist anaerobic sanitation. Probably, the creation of a regional network focussing at being an 'innovative water region' was important to prevent controversy regarding this point.

Economic and political arguments often intermingle. In discussions on novel sanitation, there was often an emphasis on small scale solutions, it was emphasized that it diminished vulnerabilities, but also that it increased the awareness of sanitation among citizens.

\section{Lock in}

Is an important issue in all cases. By a choice in favour of a new system, the old system would lose part of its value. In general, people prefer not to lose, over a gain of the same magnitude [45]. This so called 'loss aversion' explains why actors prefer solutions that include current systems over promising solutions that make the existing system superfluous. The availability of an existing 'normal' sanitation system as 'fall back' option, implies that there is less persistence in overcoming barriers to novel sanitation. The latest plans in Apeldoorn seem to be an acknowledgement of the importance of lock in, it is in fact anaerobic sanitation with maximum use of existing infrastructure.

\section{Load factor}

In various cases it was clear that especially the water boards feared the loss of demand for their existing WWTP capacity. It is not clear if this was mainly financially motivated, or if the water boards also feared that their role as being the sole 'water managers' in a region, might ultimately be at stake.

\section{Expert behaviour}

In virtually all cases it was rather clear that professionals that were in charge of running sewage systems were not very inclined to support novel sanitation. In the initial experiments, this was most clear. But also in the later cases, there was a reserved attitude among municipal engineers in control of the sewage systems. Especially their lack of expertise in relation to novel sanitation systems (and funds for complex maintenance and hiring experts) created a negative attitude. In some cases, there was a tension between the responsible politicians, and their sewage engineering experts. At the other hand, there was also a small but growing community of experts that were devoted to novel sanitation. The Wageningen scientists gradually got some support from various experts within the 'water community' such as STOWA and the Desah Company. The interest in green alternatives grew over time.

\section{User behaviour}

An anaerobic sanitation system requires low water use, which requires vacuum toilets, which in turn requires users to adapt their behaviour, e.g. toilet cleaning. Quite often, it was estimated that users would refuse to adapt their behaviour. In fact, this only happened because of toilet noise, which could easily be lowered. In general, user objections to adapting their behaviour hardly occurred.

\section{Social complexity/planning procedures}

Novel sanitation projects are more complex than traditional sanitation. This clearly played a role in the most complex project described in this paper: The Westland project aimed not just at novel anaerobic sanitation, but at creating far more symbiosis between dwellings and horticulture. The complexity required more time, which, ultimately, one 
key stakeholder refused to provide. As this time was in fact available (because of the recession), it might also have been an argument to cover unwillingness. However, also in other cases, it was clear that the complexity of the project was a factor that supported a choice in favour of standard solutions.

Sanitation systems are public systems, paid by taxes. However, public attention for the cases that were analysed in this paper was generally low (except when the crown prince opened the facilities in Sneek). In Sneek, becoming a hotspot for water innovation was a regional political issue. However, in general, public attention was minimal. As a result, political attention for the projects was less than desirable. Political decision makers were often supportive to novel sanitation. However, one did not risk a fight, if there was not much to gain.

\section{CONCLUSION AND REFLEXION}

The redline of the case studies presented in this paper is one of attempts to experiment with novel anaerobic sanitation on an increasing scale. For the proponents of a novel technology, such a line of activities makes sense, as each case might lead to lessons to be applied in the next case, and risks of failure for each case are limited. However, the stakeholders that were responsible for the sanitation in a specific city or district had different criteria of success: 'Are we able to run and maintain this system in the long term, especially if the technology will not be widely accepted'. Even when adequate niche protection for the experiment (i.e., a subsidy) was provided, expectations regarding the long term future of novel anaerobic sanitation precluded adoption. Such expectations (regarding technology, demand and resources) are socially determined, as they are especially conveyed within social groups [15, 46-48].

In the cases that were analysed in this paper, loss avoidance was important, especially for the water boards. As water boards were key actors in the cases, it seems appropriate that the threat of a loss due to existing WWTP capacities should be a major entry point for deciding on novel anaerobic sanitation projects. In the cases, the construction of new urban areas was identified as an important opportunity for experimentation (to prevent losses in existing sewage systems) but losses in WWTP capacities, due to experiments with novel sanitation, were hardly taken into regard. In fact, the project in Apeldoorn, that was briefly mentioned, took this route. The ideas that are considered in Amsterdam also take losses in WWTP capacities into regard. Hence, as a strategy towards systems transitions, it is not only important to build in pre-treatment nodes in accumulative systems, as was suggested by Frantzeskaki and Loorbach [17] but to make loss avoidance the key issue for deciding on opportunities for local niche experiments. It therefore also seems more appropriate not to take municipalities/new urban areas as the single entry point to work on a transition in sanitation. Especially water boards with tight WWTP capacities or water boards that aim at reorganising their WWTP's might be a target for introducing novel anaerobic sanitation. However, one should keep the long term future orientation in mind as too much 'loss aversion' will prohibit the required changes.

Finally, the discussion regarding novel sanitation is often dominated by a cost comparison between anaerobic sanitation and the conventional sewage/WWTP. Advantages of anaerobic sanitation systems, such as destructing medicines/chemicals in sewage (that can only be destructed in concentrated flows), recovery of resources and energy, and the options that anaerobic sanitation create for further future improvements should play a larger role in decision making.

\section{REFERENCES}

1. Brandt, N., Cambell, F., Deakin, M. and Holmstedt, L., European Cities moving towards Climate Neutrality Participation, Indicators and Benchmarking, E. I. C. 
Project, City of Stockholm: Stockholm, Technical Report, 2014, https://doi.org/10.13140/2.1.3166.3369

2. Kaijser, A., In the Fathers Track: The Historical development of the Swedish Infrastructure and Future challenges (in Swedish), Carlsson, Sweden, 1994.

3. Constant, E. W., The Social Locus of Technological Practice: Community, System, or Organization (Chapter), The Social Construction of Technological Systems: New Directions in the Sociology and History of Technology (Bijker, W. E., Parke Hughes, T. and Pinch, T., eds.), pp 223-242, MIT Press, London, UK, 1987.

4. Schumpeter, J. A., Capitalism, Socialism and Democracy, Routledge, Abington, UK, 2010, https://doi.org/10.4324/9780203857090

5. Hughes, T. P., Networks of Power: Electrification in Western Society, 1880-1930, Baltimore: John Hopkins University Press, Baltimore, USA, 1985.

6. Bijker, W. E., Hughes, T. P. and Pinch, T. J., The Social Construction of Technological Systems: New Directions in the Sociology and History of Technology, 405 p, MIT Press, Cambridge, USA, 1987.

7. Arthur, W. B., Competing Technologies, Increasing Returns, and Lock-in by Historical Events, The Economic Journal, Vol. 99, No. 394, pp 116-131, 1989, https://doi.org/10.2307/2234208

8. Liebowitz, S. J. and Margolis, S. E., Path Dependence, Lock-in, and History, Journal of Law, Economics \& Organisation, Vol. 11, No. 1, pp 205-226, 1995, https://doi.org/10.2139/ssrn.1706450

9. Schot, J., Hoogma, R. and Elzen, B., Strategies for Shifting Technological Systems: The Case of the Automobile System, Futures, Vol. 26, No. 10, pp 1060-1076, 1994, https://doi.org/10.1016/0016-3287(94)90073-6

10. Kemp, R., Technology and the Transition to Environmental Sustainability: The Problem of Technological Regime Shifts, Futures, Vol. 26, No. 10, pp 1023-1046, 1994, https://doi.org/10.1016/0016-3287(94)90071-X

11. Holmberg, J. and Robèrt, K. H., Backcasting - A Framework for Strategic Planning, International Journal of Sustainable Development and World Ecology, Vol. 7, No. 4, pp 291-308, 2000, https://doi.org/10.1080/13504500009470049

12. Rotmans, J., Kemp, R. and Van Asselt, M., More Evolution than Revolution: Transition management in Public Policy, Foresight, Vol. 3, No. 1, pp 15-31, 2001, https://doi.org/10.1108/14636680110803003

13. Geels, F. W., Technological Transitions as Evolutionary Reconfiguration Processes: A Multi-level Perspective and a Case-study, Research Policy, Vol. 31, No. 8, pp 1257-1274, 2002, https://doi.org/10.1016/S0048-7333(02)00062-8

14. van Lente, H., Hekkert, M. P., Smits, R. and van Waveren, B., Roles of Systemic Intermediaries in Transition Processes, International Journal of Innovation Management, Vol. 7, No. 3, pp 247-279, 2003, https://doi.org/10.1142/S1363919603000817

15. Rip, A., Expectations and Strategic Niche management in Technological developments, Conference Paper, International Conference Inside Technology, Torino, Italy, 1989.

16. Kemp, R., Schot, J. and Hoogma, R., Regime shifts to Sustainability through Processes of Niche Formation: The approach of Strategic Niche management, Technology Analysis \& Strategic Management, Vol. 10, No. 2, pp 175-198, 1998, https://doi.org/10.1080/09537329808524310

17. Frantzeskaki, N. and Loorbach, D., Towards governing Infrasystem transitions: Reinforcing Lock-in or facilitating change?, Technological Forecasting and Social Change, Vol. 77, No. 8, pp 1292-1301, 2010, https://doi.org/10.1016/j.techfore.2010.05.004

18. Eijlander, S. and Mulder, K. F., Sanitary Systems: Challenges for Innovation, Conference Paper, SDEWES 2017, Dubrovnik, Croatia, 2017. 
19. Mulder, K., The Metabolism of the City (in Dutch), Haagse Hogeschool, Den Haag, Netherlands, 2016.

20. Cieślik, B. M., Namieśnik, J. and Konieczka, P., Review of Sewage Sludge management: Standards, Regulations and Analytical Methods, Journal of Cleaner Production, Vol. 90, pp 1-15, 2015, https://doi.org/10.1016/j.jclepro.2014.11.031

21. Barros, N., Cole, J. J., Tranvik, L. J., Prairie, Y. T., Bastviken, D., Huszar, V. L. M., del Giorgio, P. and Roland, F., Carbon emission from Hydroelectric Reservoirs linked to Reservoir age and latitude, Nature Geoscience, Vol. 4, No. 9, pp 593-596, 2011, https://doi.org/10.1038/ngeo1211

22. Verbong, G. and Raven, R., Dung, Sludge, and Landfill: Biogas Technology in the Netherlands, 1970-2000, Technology and Culture, Vol. 45, No. 3, pp 519-539, 2004, https://doi.org/10.1353/tech.2004.0149

23. Musee, N. and Lorenzen, L., Market Dynamics as a Driver towards the evolution of research needs: The Case of up-flow anaerobic Sludge Blanket seeding Granules, Water SA, Vol. 39, No. 1, pp 131-142, 2013, https://doi.org/10.4314/wsa.v39i1.13

24. Tilley, E., Ulrich, L., Luthi, C., Reymond, P. and Zurbrugg, C., Compendium of Sanitation Systems and Technologies, Swiss Federal Institute of Aquatic Science and Technology (EAWAG), Duebendorf, Switzerland, 2014.

25. STOWA, Evaluation new sanitation of Noorderhoek Sneek (in Dutch) (Hermans, W. B. P., ed.), p 33, STOWA, Amersfoort, Netherlands, 2014.

26. Andersson, K. and Castor, M., Treatment of Black Water and Food Waste with Anaerobic Membrane Bioreactor and Reverse Osmosis (in Swedish), Lund Technical University, Lund, Sweden, 2006.

27. Hegger, D., Greening Sanitary Systems: An End-user Perspective, Wageningen University \& Research, Wageningen, Netherlands, 2007.

28. Wendland, C., Deegener, S., Behrendt, J., Toshev, P. and Otterpohl, R., Anaerobic digestion of Blackwater from Vacuum Toilets and Kitchen refuse in a continuous stirred Tank Reactor (CSTR), Water Science and Technology, Vol. 55, No. 7, pp 187-194, 2007, https://doi.org/10.2166/wst.2007.144

29. An Introduction to the Vauban District, https://www.vauban.de/en/topics/history/276-an-introduction-to-vauban-district, [Accessed: 10-April-2018]

30. 'Suction Toilet' attracts State Secretary (in Dutch), Leeuwarder Courant, 2009.

31. Municipalities in charge by dip housing Market (in Dutch), Leeuwarder Courant, 2009.

32. Noorderhoek innovative Experimental Garden (in Dutch), Sneeker Nieuwsblad, p 1, Sneek, Netherlands, 2009.

33. Pennewaard, K., Everything in the Kitchen Grinder (in Dutch), Leeuwarder Courant, Leeuwarden, Netherlands, 2011.

34. Water Project continued in Noorderhoek (in Dutch), Leeuwarder Courant, p 30, Leeuwarden, Netherlands, 2015.

35. Wortmann, E. and Kruseman, I., The Sun Eater - A Large-scale Sun Project (in Dutch), InnovatieNetwerk Groene Ruimte en Agrocluster Utrecht, Utrecht, Netherlands, 2005.

36. Van Andel, E., Heat exchanger and method for manufacturing same, Google Patents, 1998.

37. Grin, J. and Staveren, A., Working on System innovations: Lessons from the Practice of InnovationNetwork (in Dutch), Koninklijke Van Gorcum, Assen, Netherlands, 2007.

38. Wortmann, E., New sanitation Westland (in Dutch), STOWA, 2010.

39. Delft, M.A.o., Sustainable Area development of New Delft (in Dutch), Municipality: Delft, Delft, Netherlands, 2014. 
40. Rail Tunnel puts the Municipality of Delft under Water (in Dutch), Trouw, Netherlands, 2014.

41. Berg, R., van den Bulk, J. and Wiersma, L., New sanitation Apeldoorn 2: (NSA II) (in Dutch), STOWA, 2013.

42. Steenwinkel, R. and Anleo, M. G. G., New Sanitation (in Dutch), 2018, https://www.waternet.nl/werkzaamheden/nieuwe-sanitatie/, [Accessed: 10-April-2018]

43. Chakrabarti, A. K., The Role of Champion in Product Innovation, California Management Review, Vol. 17, No. 2, pp 58-62, 1974, https://doi.org/10.2307/41164561

44. Callon, M., The Sociology of an Actornetwork: The Case of the Electric Vehicle, in Mapping the Dynamics of Science and Technology (Callon, M., Law, D. and Rip, A., eds.), pp 19-34, MacMillan, London, UK, 1986, https://doi.org/10.1007/978-1-349-07408-2_2

45. Tversky, A. and Kahneman, D., Advances in Prospect Theory: Cumulative representation of uncertainty, Journal of Risk and Uncertainty, Vol. 5, No. 4, pp 297-323, 1992, https://doi.org/10.1007/BF00122574

46. Mulder, K., Ferrer, D. and van Lente, H., What is Sustainable Technology?: Perceptions, Paradoxes and Possibilities, Greenleaf Publishing, Abingdon, UK, 2011.

47. van Lente, H., Navigating foresight in a Sea of Expectations: Lessons from the Sociology of Expectations, Technology Analysis \& Strategic Management, Vol. 24, No. 8, pp 769-782, 2012, https://doi.org/10.1080/09537325.2012.715478

48. van Lente, H. and van Til, J. I., Articulation of sustainability in the emerging Field of Nanocoatings, Journal of Cleaner Production, Vol. 16, No. 8, pp 967-976, 2008, https://doi.org/10.1016/j.jclepro.2007.04.020 